\title{
Is Hypoxic/Altitude Training an Important Topic in the Field of Hypoxia?
}

\author{
Grégoire P. Millet ${ }^{1,2}$ (1) $\cdot$ Martin Burtscher ${ }^{3}$ Johannes Burtscher ${ }^{1,2}$
}

Received: 16 August 2021 / Accepted: 29 September 2021 / Published online: 9 December 2021

(c) The Author(s) 2021

\begin{abstract}
Hypoxia is an essential topic in medical or biological sciences. The main aims of the present study were to examine the most important medical articles (i.e., the top 100 most cited) on hypoxia. We examine how the Nobel-prize awarded hypoxia inducible factor (HIF)-pathway discovery in the early 1990s has changed the thematic composition of this body of literature, with a special emphasis on the studies linking hypoxia and cancer. We searched Pubmed for articles with the terms \#Hypox, \#Altitude, or \#Mountain in the title that have been published in biomedical journals and ranked the articles on their number of citations in Web of Science. A second search was performed in all journals for articles related to hypoxia and cancer. Strikingly, only 12 of the top- 100 most-cited articles on hypoxia and only 3 articles of the top-100 articles related to cancer were published before 1995. Moreover, only 5 articles from prior 1995 reached 1000 citations, while 27 articles published in 1995 or later were cited more than 1000 times, most of them on the HIF-1 pathway. Eighty percent of the top-100 articles were related to the HIF pathway, while there were no articles on the application of hypoxia either for therapeutic use (i.e., hypoxic conditioning in patients) or for performance enhancement (i.e., altitude training in athletes). In conclusion, the early-1990s discovery of the HIF pathway and of its molecular regulation has shifted the focus of hypoxia research towards molecular mechanisms and consequences of tissue hypoxia, most notably in cancer. The importance of studies focusing on clinical and performance applications of systemic hypoxia is relatively lower.
\end{abstract}

Keywords Altitude training $\cdot$ Cancer $\cdot$ Hypoxia $\cdot$ HIF pathway $\cdot$ Mountain

\section{Introduction}

Between 1775 and 1777, Scheele [103] and Priestley [93] found a previously unknown gas in the air that was named "oxygen" by Lavoisier [64]. This fundamental finding paved the way for the understanding of the primary importance of the metabolic and physiological adaptations to oxygen availability and consequently to "The history of hypoxia" as elegantly reported by Richalet [98]. The Nobel prize in physiology or medicine for 2019 awarded to William Kaelin Jr, Sir Peter Ratcliffe, and Gregg Semenza for their work

Grégoire P. Millet

gregoire.millet@unil.ch

1 Institute of Sport Sciences, University of Lausanne, Campus Dorigny, 1015 Lausanne, Switzerland

2 Department of Biomedical Sciences, University of Lausanne, 1015 Lausanne, Switzerland

3 Department of Sport Science, University of Innsbruck, Innsbruck, Austria on the molecular mechanisms underlying how cells adapt to different levels of oxygen supply is the most prestigious event of this long journey.

Since the 1950s, the term "hypoxia" (i.e., "abnormal condition resulting from a decrease in the oxygen supplied to or utilized by body tissue"; Webster's New World College Dictionary, 4th ed 2010; from [98]) has been increasingly deployed in the medical or biological scientific literature:

1. In environmental physiology, to deepen the understanding of the physiological (i.e., cardiovascular and respiratory adaptations) and pathophysiological (i.e., acute mountain sickness) responses to severe hypoxia (e.g., in aviation physiology [34]) or to high altitude, as pioneered at the end of 19th-early twentieth century in Europe [97] and USA [134]).

2. With the development of cellular or molecular biology, to understand how variations in oxygen delivery lead to changes in gene transcription and to adaptive responses in cells and tissues. The importance of the isolation 
of the hypoxia inducible factor (HIF) has been unanimously recognized and celebrated by bestowal of the Nobel Prize [83]. The subsequent growing understanding of its role in cellular pathways and its molecular regulation, e.g., by the von Hippel-Lindau (VHL) protein, contributed to the recognition of various potential (clinical) applications, especially with regard to associated drug targets in various cancers [125]. Various HIF molecules and subunits (HIF- $1 \alpha$, HIF- $1 \beta$, HIF- $2 \alpha$, HIF- $2 \beta$, HIF- $3 \alpha$, HIF- $3 \beta$ ) have been characterized and our understanding of their differential roles has increased substantially during the last decades. For example, the unique target genes of HIF- $1 \alpha$ and HIF- $2 \alpha$ and their different functions in glycolytic regulation, glucose consumption, or hypoxia responses are being continuously unraveled [50].

Numerous applications of hypoxia have also been investigated and published in the scientific literature:

3. In the clinical field, the continuous exposure to altitude or systemic intermittent hypoxic conditioning/training (not to be confused with pathology-associated "intermittent hypoxia" as in sleep apnea, for example) has been proposed to be an effective treatment strategy against different diseases, conferring various health benefits: e.g., cardioprotection [77]; neuroprotection [13]; and reduction of obesity [135]; cancer mortality [14], and cardiovascular diseases [28, 29].

4. Since the 1960 s for enhancing performance in athletes, initially only in endurance sports due to the hematological benefit of prolonged exposure to altitude $[23,74]$ and more recently in intermittent (i.e., team or racket) sports $[36,82]$.

To our knowledge, there is no detailed analysis of the scientific contributions related to hypoxia. The main aims of the present study were to examine the most important (i.e., the most-cited) articles in this field and to examine how the HIF-pathway discovery may have changed the thematic composition of this body of literature, with a special emphasis on the studies linking hypoxia and cancer. Finally, the relative representation in hypoxia research of five different topics (pathophysiological responses to high altitude; physiological adaptive responses to hypoxia; molecular responses to hypoxia; clinical/therapeutic use of hypoxia; altitude training) was analyzed.

\section{Methods}

We first identified biomedical (biology, medicine, physiology, or "sport sciences") journals in PubMed (https:// pubmed.ncbi.nlm.nih.gov/) with potential articles on altitude or hypoxia. All journals with the terms \#Med, \#Physiol, \#Biol, \#Exerc, and \#Cell in the journal name were first selected. For inclusion of the highest ranked general scientific and medical journals, we added journals with \#Sci, \#Lancet, \#Jama, \#Nature, \#PNAS, and \#BMJ in their names.

This yielded a list of 1726 journals or source titles. From this list, we removed those that were not closely related to human physiology or medicine (e.g., plants, veterinary, zoology, animals) reducing the list to 1668 journals.

Next we searched Pubmed for articles with the terms Hypox*, Altitude, or Mountain* in the title. This yielded 29,888 articles on the 15th march 2021.

The next step was to determine the number of citations for these articles. We performed a complete search for all the articles on Web of Science (https://www.webofscience. $\mathrm{com} /$ ) on 16-17th march 2021. Basic information, including source journal, publication year, citations per year, and total number of citations, was extracted.

These publications were then ranked by the number of times cited and a list of the top-100 cited articles was created. Finally, we extracted from this list all articles related to cancer (i.e., titles containing the terms "tumour"/"tumor" or "cancer"), yielding a list of the top100 articles on hypoxia but without a primary focus on cancer (Table 1).

Each of these 100 articles was then analyzed by two independent reviewers (GPM and JB) to classify them according to five distinct categories, regarding their main purpose:

1. Pathophysiological responses to high altitude-focus on adverse/maladaptive systemic physiological effects to hypoxia or high altitude.

2. Physiological responses to hypoxia-focus on adaptive systemic physiological and genetic effects to hypoxia.

3. Molecular responses to hypoxia-mechanistic studies with a focus on cell physiology and pathology.

4. Clinical/therapeutic use of hypoxia-therapeutic use of hypoxia in clinical populations, except cancer.

5. Altitude training — use of altitude/hypoxia for sport performance enhancement purpose.

A second search in Pubmed was performed in all journals for articles related to hypoxia and cancer, i.e., articles with \#Hypox or \#Altitude and \#cancer in the title. This search yielded 3173 articles. As described for Table 1, we ranked 
Table 1 Top-100 cited articles on "hypoxia"

Order References

Citations

number

1 [130] Wang GL, Jiang BH, Rue EA, Semenza GL. Hypoxia-inducible factor 1 is a basic-helix-loop-helix-PAS heterodimer regulated by cellular O2 tension. Proc Natl Acad Sci U S A. 1995;92(12):5510-5514

2 [120] Shweiki D, Itin A, Soffer D, Keshet E. Vascular endothelial growth factor induced by hypoxia may mediate hypoxia-initiated angiogenesis. Nature. 1992;359(6398):843-845

$3 \quad[79]$

Maxwell PH, Wiesener MS, Chang GW, et al. The tumour suppressor protein VHL targets hypoxia-inducible factors for oxygen-dependent proteolysis. Nature. 1999;399(6733):271-275 hypoxia-inducible factor 1. Mol Cell Biol. 1996;16(9):4604-4613

Kim JW, Tchernyshyov I, Semenza GL, Dang CV. HIF-1-mediated expression of pyruvate dehydrogenase kinase: a 2103 metabolic switch required for cellular adaptation to hypoxia. Cell Metab. 2006;3(3):177-185

Ceradini DJ, Kulkarni AR, Callaghan MJ, et al. Progenitor cell trafficking is regulated by hypoxic gradients through HIF-1 induction of SDF-1. Nat Med. 2004;10(8):858-864

Pugh CW, Ratcliffe PJ. Regulation of angiogenesis by hypoxia: role of the HIF system. Nat Med. 2003;9(6):677-684

Shankaran S, Laptook AR, Ehrenkranz RA, et al. Whole-body hypothermia for neonates with hypoxic-ischemic encephalopathy. N Engl J Med. 2005;353(15):1574-1584

Semenza GL. Regulation of mammalian O2 homeostasis by hypoxia-inducible factor 1. Annu Rev Cell Dev Biol. 1999;15:551-578

11 [133] Wang GL, Semenza GL. Purification and characterization of hypoxia-inducible factor 1. J Biol Chem. 1995;270(3):1230-1237

Chandel NS, Maltepe E, Goldwasser E, Mathieu CE, Simon MC, Schumacker PT. Mitochondrial reactive oxygen species trigger hypoxia-induced transcription. Proc Natl Acad Sci U S A. 1998;95(20):11715-11720

Semenza GL. HIF-1: mediator of physiological and pathophysiological responses to hypoxia. J Appl Physiol (1985). 2000;88(4):1474-1480

14 [89] Papandreou I, Cairns RA, Fontana L, Lim AL, Denko NC. HIF-1 mediates adaptation to hypoxia by actively downregulating mitochondrial oxygen consumption. Cell Metab. 2006;3(3):187-197

Semenza GL, Roth PH, Fang HM, Wang GL. Transcriptional regulation of genes encoding glycolytic enzymes by hypoxia-inducible factor 1. J Biol Chem. 1994;269(38):23,757-23,763

Chandel NS, McClintock DS, Feliciano CE, et al. Reactive oxygen species generated at mitochondrial complex III stabilize hypoxia-inducible factor-1alpha during hypoxia: a mechanism of O2 sensing. J Biol Chem. 2000;275(33):25130-25138

Salceda S, Caro J. Hypoxia-inducible factor 1alpha (HIF-1alpha) protein is rapidly degraded by the ubiquitin-proteasome system under normoxic conditions. Its stabilization by hypoxia depends on redox-induced changes. $\mathrm{J}$ Biol Chem. 1997;272(36):22642-22647

Majmundar AJ, Wong WJ, Simon MC. Hypoxia-inducible factors and the response to hypoxic stress. Mol Cell. 2010;40(2):294-309

19 [108] Semenza GL, Jiang BH, Leung SW, et al. Hypoxia response elements in the aldolase A, enolase 1, and lactate dehydrogenase A gene promoters contain essential binding sites for hypoxia-inducible factor 1 . J Biol Chem. 1996;271(51):32529-32537

Long term domiciliary oxygen therapy in chronic hypoxic cor pulmonale complicating chronic bronchitis and emphysema. Report of the Medical Research Council Working Party. Lancet. 1981;1(8222):681-686

Lando D, Peet DJ, Whelan DA, Gorman JJ, Whitelaw ML. Asparagine hydroxylation of the HIF transactivation domain a hypoxic switch. Science. 2002;295(5556):858-861

Ohh M, Park CW, Ivan M, et al. Ubiquitination of hypoxia-inducible factor requires direct binding to the betadomain of the von Hippel-Lindau protein. Nat Cell Biol. 2000;2(7):423-427

23 [5] Berne RM. Cardiac nucleotides in hypoxia: possible role in regulation of coronary blood flow. Am J Physiol. 1963;204:317-322 response to hypoxia. J Biol Chem. 2008;283(16):10892-10903

27 [63] Laughner E, Taghavi P, Chiles K, Mahon PC, Semenza GL. HER2 (neu) signaling increases the rate of hypoxiainducible factor 1alpha (HIF-1alpha) synthesis: novel mechanism for HIF-1-mediated vascular endothelial growth factor expression. Mol Cell Biol. 2001;21(12):3995-4004 
Table 1 (continued)

Order References

Citations

number

$\begin{array}{lll}28 * & {[12]} & \begin{array}{l}\text { Bunn HF, Poyton RO. Oxygen sensing and molecular adaptation to hypoxia. Physiol Rev. 1996;76(3):839-885 } \\ \text { Guzy RD, Hoyos B, Robin E, et al. Mitochondrial complex III is required for hypoxia-induced ROS production and } \\ \text { cellular oxygen sensing. Cell Metab. 2005;1(6):401-408 }\end{array} \\ 30 & {[40]} & \begin{array}{l}\text { Rius J, Guma M, Schachtrup C, et al. NF-kappaB links innate immunity to the hypoxic response through transcrip- } \\ \text { tional regulation of HIF-1alpha. Nature. 2008;453(7196):807-811 }\end{array}\end{array}$

31 [81] Metallo CM, Gameiro PA, Bell EL, et al. Reductive glutamine metabolism by IDH1 mediates lipogenesis under hypoxia. Nature. 2011;481(7381):380-384 marily upon redox-sensitive stabilization of its alpha subunit. J Biol Chem. 1996;271(50):32253-32259

Hochachka PW. Defense strategies against hypoxia and hypothermia. Science. 1986;231(4735):234-241

Hudson CC, Liu M, Chiang GG, et al. Regulation of hypoxia-inducible factor 1alpha expression and function by the mammalian target of rapamycin. Mol Cell Biol. 2002;22(20):7004-7014

Hu CJ, Wang LY, Chodosh LA, Keith B, Simon MC. Differential roles of hypoxia-inducible factor 1alpha (HIF1alpha) and HIF-2alpha in hypoxic gene regulation. Mol Cell Biol. 2003;23(24):9361-9374

Yi X, Liang Y, Huerta-Sanchez E, et al. Sequencing of 50 human exomes reveals adaptation to high altitude. Science. 2010;329(5987):75-78

Bellot G, Garcia-Medina R, Gounon P, et al. Hypoxia-induced autophagy is mediated through hypoxia-inducible factor induction of BNIP3 and BNIP3L via their BH3 domains. Mol Cell Biol. 2009;29(10):2570-2581

Dang EV, Barbi J, Yang HY, et al. Control of T(H)17/T(reg) balance by hypoxia-inducible factor 1. Cell. 2011;146(5):772-784

Jiang BH, Rue E, Wang GL, Roe R, Semenza GL. Dimerization, DNA binding, and transactivation properties of hypoxia-inducible factor 1. J Biol Chem. 1996;271(30):17771-17778

Hackett PH, Roach RC. High-altitude illness. N Engl J Med. 2001;345(2):107-114

Levy AP, Levy NS, Wegner S, Goldberg MA. Transcriptional regulation of the rat vascular endothelial growth factor gene by hypoxia. J Biol Chem. 1995;270(22):13333-13340

Cockman ME, Masson N, Mole DR, et al. Hypoxia inducible factor-alpha binding and ubiquitylation by the von Hippel-Lindau tumor suppressor protein. J Biol Chem. 2000;275(33):25,733-25,741

Gustafsson MV, Zheng X, Pereira T, et al. Hypoxia requires notch signaling to maintain the undifferentiated cell state. Dev Cell. 2005;9(5):617-628

Kulshreshtha R, Ferracin M, Wojcik SE, et al. A microRNA signature of hypoxia. Mol Cell Biol. 2007;27(5):1859-1867

Li C, Jackson RM. Reactive species mechanisms of cellular hypoxia-reoxygenation injury. Am J Physiol Cell Physiol. 2002;282(2):C227-241

Fukuda R, Zhang H, Kim JW, Shimoda L, Dang CV, Semenza GL. HIF-1 regulates cytochrome oxidase subunits to optimize efficiency of respiration in hypoxic cells. Cell. 2007;129(1):111-122

Hochachka PW, Buck LT, Doll CJ, Land SC. Unifying theory of hypoxia tolerance: molecular/metabolic defense and rescue mechanisms for surviving oxygen lack. Proc Natl Acad Sci U S A. 1996;93(18):9493-9498

Ema M, Taya S, Yokotani N, Sogawa K, Matsuda Y, Fujii-Kuriyama Y. A novel bHLH-PAS factor with close sequence similarity to hypoxia-inducible factor 1alpha regulates the VEGF expression and is potentially involved in lung and vascular development. Proc Natl Acad Sci U S A. 1997;94(9):4273-4278

Semenza GL. HIF-1 and mechanisms of hypoxia sensing. Curr Opin Cell Biol. 2001;13(2):167-171 hypoxia enhanced MDSC-mediated T cell activation. J Exp Med. 2014;211(5):781-790

Luo W, Hu H, Chang R, et al. Pyruvate kinase M2 is a PHD3-stimulated coactivator for hypoxia-inducible factor 1.762 Cell. 2011;145(5):732-744

Mu J, Brozinick JT, Jr., Valladares O, Bucan M, Birnbaum MJ. A role for AMP-activated protein kinase in contraction- and hypoxia-regulated glucose transport in skeletal muscle. Mol Cell. 2001;7(5):1085-1094

Semenza GL. Hypoxia-inducible factor 1: oxygen homeostasis and disease pathophysiology. Trends Mol Med. 2001;7(8):345-350

Somjen GG. Mechanisms of spreading depression and hypoxic spreading depression-like depolarization. Physiol Rev. 2001;81(3):1065-1096

Appelhoff RJ, Tian YM, Raval RR, et al. Differential function of the prolyl hydroxylases PHD1, PHD2, and PHD3 in the regulation of hypoxia-inducible factor. J Biol Chem. 2004;279(37):38458-38465 
Table 1 (continued)

Order References

number

56 [1] An WG, Kanekal M, Simon MC, Maltepe E, Blagosklonny MV, Neckers LM. Stabilization of wild-type p53 by 727
hypoxia-inducible factor 1alpha. Nature. 1998;392(6674):405-408

57 [132] Wang GL, Semenza GL. Characterization of hypoxia-inducible factor 1 and regulation of DNA binding activity by 722 hypoxia. J Biol Chem. 1993;268(29):21513-21518

58* [111] Semenza GL. HIF-1, O(2), and the 3 PHDs: how animal cells signal hypoxia to the nucleus. Cell. 2001;107(1):1-3

59 [122] Simonson TS, Yang Y, Huff CD, et al. Genetic evidence for high-altitude adaptation in Tibet. Science. 2010;329(5987):72-75

60 [30] Fasanaro P, D'Alessandra Y, Di Stefano V, et al. MicroRNA-210 modulates endothelial cell response to hypoxia and inhibits the receptor tyrosine kinase ligand Ephrin-A3. J Biol Chem. 2008;283(23):15878-15883

61 [72] Liu L, Feng D, Chen G, et al. Mitochondrial outer-membrane protein FUNDC1 mediates hypoxia-induced mitophagy in mammalian cells. Nat Cell Biol. 2012;14(2):177-185

62 K56] Kallio PJ, Wilson WJ, O'Brien S, Makino Y, Poellinger L. Regulation of the hypoxia-inducible transcription factor 1alpha by the ubiquitin-proteasome pathway. J Biol Chem. 1999;274(10):6519-6525

63

$64 \quad[104]$

$65 \quad[106]$

[106] Semenza GL, Nejfelt MK, Chi SM, Antonarakis SE. Hypoxia-inducible nuclear factors bind to an enhancer element located 3' to the human erythropoietin gene. Proc Natl Acad Sci U S A. 1991;88(13):5680-5684

$66 \quad[35]$

Iliopoulos O, Levy AP, Jiang C, Kaelin WG Jr., Goldberg MA. Negative regulation of hypoxia-inducible genes by the von Hippel-Lindau protein. Proc Natl Acad Sci U S A. 1996;93(20):10595-10599

Schioppa T, Uranchimeg B, Saccani A, et al. Regulation of the chemokine receptor CXCR4 by hypoxia. J Exp Med. 2003;198(9):1391-1402

Gerber HP, Condorelli F, Park J, Ferrara N. Differential transcriptional regulation of the two vascular endothelial growth factor receptor genes. Flt-1, but not Flk-1/KDR, is up-regulated by hypoxia. J Biol Chem. 1997;272(38):23659-23667

Bruick RK. Expression of the gene encoding the proapoptotic Nip3 protein is induced by hypoxia. Proc Natl Acad Sci U S A. 2000;97(16):9082-9087

Daut J, Maier-Rudolph W, von Beckerath N, Mehrke G, Gunther K, Goedel-Meinen L. Hypoxic dilation of coronary arteries is mediated by ATP-sensitive potassium channels. Science. 1990;247(4948):1341-1344

Parmar K, Mauch P, Vergilio JA, Sackstein R, Down JD. Distribution of hematopoietic stem cells in the bone marrow according to regional hypoxia. Proc Natl Acad Sci U S A. 2007;104(13):5431-5436

Semenza GL. Regulation of oxygen homeostasis by hypoxia-inducible factor 1. Physiology (Bethesda). 2009;24:97-106

Shimizu S, Eguchi Y, Kosaka H, Kamiike W, Matsuda H, Tsujimoto Y. Prevention of hypoxia-induced cell death by Bcl-2 and Bcl-xL. Nature. 1995;374(6525):811-813

Schmedtje JF, Jr., Ji YS, Liu WL, DuBois RN, Runge MS. Hypoxia induces cyclooxygenase-2 via the NF-kappaB p65 transcription factor in human vascular endothelial cells. J Biol Chem. 1997;272(1):601-608

Hirsila M, Koivunen P, Gunzler V, Kivirikko KI, Myllyharju J. Characterization of the human prolyl 4-hydroxylases that modify the hypoxia-inducible factor. J Biol Chem. 2003;278(33):30772-30780

Simsek T, Kocabas F, Zheng J, et al. The distinct metabolic profile of hematopoietic stem cells reflects their location in a hypoxic niche. Cell Stem Cell. 2010;7(3):380-390

[137] Wise DR, Ward PS, Shay JE, et al. Hypoxia promotes isocitrate dehydrogenase-dependent carboxylation of alphaketoglutarate to citrate to support cell growth and viability. Proc Natl Acad Sci U S A. 2011;108(49):1961119616

Lee PJ, Jiang BH, Chin BY, et al. Hypoxia-inducible factor-1 mediates transcriptional activation of the heme oxygenase-1 gene in response to hypoxia. J Biol Chem. 1997;272(9):5375-5381

Guzy RD, Schumacker PT. Oxygen sensing by mitochondria at complex III: the paradox of increased reactive oxygen species during hypoxia. Exp Physiol. 2006;91(5):807-819

78 [127] Vanden Hoek TL, Becker LB, Shao Z, Li C, Schumacker PT. Reactive oxygen species released from mitochondria during brief hypoxia induce preconditioning in cardiomyocytes. J Biol Chem. 1998;273(29):18092-18098

Ye J, Gao Z, Yin J, He Q. Hypoxia is a potential risk factor for chronic inflammation and adiponectin reduction in adipose tissue of ob/ob and dietary obese mice. Am J Physiol Endocrinol Metab. 2007;293(4):E1118-1128

Arany Z, Huang LE, Eckner R, et al. An essential role for p300/CBP in the cellular response to hypoxia. Proc Natl Acad Sci U S A. 1996;93(23):12969-12973

$81 \quad[44]$ 
Table 1 (continued)

Order References

number

\begin{tabular}{|c|c|c|c|}
\hline 82 & [86] & $\begin{array}{l}\text { Neonatal Inhaled Nitric Oxide Study G. Inhaled nitric oxide in full-term and nearly full-term infants with hypoxic } \\
\text { respiratory failure. N Engl J Med. 1997;336(9):597-604 }\end{array}$ & 576 \\
\hline 83 & [37] & $\begin{array}{l}\text { Graeber TG, Peterson JF, Tsai M, Monica K, Fornace AJ Jr., Giaccia AJ. Hypoxia induces accumulation of p53 } \\
\text { protein, but activation of a G1-phase checkpoint by low-oxygen conditions is independent of p53 status. Mol Cell } \\
\text { Biol. 1994;14(9):6264-6277 }\end{array}$ & 569 \\
\hline $84 *$ & [16] & $\begin{array}{l}\text { Carreau A, El Hafny-Rahbi B, Matejuk A, Grillon C, Kieda C. Why is the partial oxygen pressure of human tissues } \\
\text { a crucial parameter? Small molecules and hypoxia. J Cell Mol Med. 2011;15(6):1239-1253 }\end{array}$ & 565 \\
\hline 85 & [24] & $\begin{array}{l}\text { Duranteau J, Chandel NS, Kulisz A, Shao Z, Schumacker PT. Intracellular signaling by reactive oxygen species } \\
\text { during hypoxia in cardiomyocytes. J Biol Chem. 1998;273(19):11619-11624 }\end{array}$ & 556 \\
\hline 86 & [69] & $\begin{array}{l}\text { Levy AP, Levy NS, Goldberg MA. Post-transcriptional regulation of vascular endothelial growth factor by } \\
\text { hypoxia. J Biol Chem. 1996;271(5):2746-2753 }\end{array}$ & 547 \\
\hline 87 & [143] & $\begin{array}{l}\text { Yoshida Y, Takahashi K, Okita K, Ichisaka T, Yamanaka S. Hypoxia enhances the generation of induced pluripo- } \\
\text { tent stem cells. Cell Stem Cell. 2009;5(3):237-241 }\end{array}$ & 546 \\
\hline 88 & [126] & $\begin{array}{l}\text { Ullah MS, Davies AJ, Halestrap AP. The plasma membrane lactate transporter MCT4, but not MCT1, is up-regu- } \\
\text { lated by hypoxia through a HIF-1alpha-dependent mechanism. J Biol Chem. 2006;281(14):9030-9037 }\end{array}$ & 545 \\
\hline 89 & [45] & $\begin{array}{l}\text { Hewitson KS, McNeill LA, Riordan MV, et al. Hypoxia-inducible factor (HIF) asparagine hydroxylase is identical } \\
\text { to factor inhibiting HIF (FIH) and is related to the cupin structural family. J Biol Chem. 2002;277(29):26351- } \\
26355\end{array}$ & 542 \\
\hline 90 & [85] & $\begin{array}{l}\text { Mukhopadhyay D, Tsiokas L, Zhou XM, Foster D, Brugge JS, Sukhatme VP. Hypoxic induction of human vascu- } \\
\text { lar endothelial growth factor expression through c-Src activation. Nature. 1995;375(6532):577-581 }\end{array}$ & 541 \\
\hline 91 & [129] & $\begin{array}{l}\text { Walmsley SR, Print C, Farahi N, et al. Hypoxia-induced neutrophil survival is mediated by HIF-1alpha-dependent } \\
\text { NF-kappaB activity. J Exp Med. 2005;201(1):105-115 }\end{array}$ & 537 \\
\hline 92 & [54] & $\begin{array}{l}\text { Isaacs JS, Jung YJ, Mimnaugh EG, Martinez A, Cuttitta F, Neckers LM. Hsp90 regulates a von Hippel Lindau- } \\
\text { independent hypoxia-inducible factor-1 alpha-degradative pathway. J Biol Chem. 2002;277(33):29936-29944 }\end{array}$ & 537 \\
\hline 93 & [100] & $\begin{array}{l}\text { Rubanyi GM, Vanhoutte PM. Hypoxia releases a vasoconstrictor substance from the canine vascular endothelium. } \\
\text { J Physiol. 1985;364:45-56 }\end{array}$ & 536 \\
\hline 94 & [68] & $\begin{array}{l}\text { Levy NS, Chung S, Furneaux H, Levy AP. Hypoxic stabilization of vascular endothelial growth factor mRNA by } \\
\text { the RNA-binding protein HuR. J Biol Chem. 1998;273(11):6417-6423 }\end{array}$ & 535 \\
\hline 95 & [140] & $\begin{array}{l}\text { Yaffe K, Laffan AM, Harrison SL, et al. Sleep-disordered breathing, hypoxia, and risk of mild cognitive impair- } \\
\text { ment and dementia in older women. JAMA. 2011;306(6):613-619 }\end{array}$ & 533 \\
\hline 96 & [42] & $\begin{array}{l}\text { Hackett PH, Rennie D, Levine HD. The incidence, importance, and prophylaxis of acute mountain sickness. Lan- } \\
\text { cet. 1976;2(7996):1149-1155 }\end{array}$ & 529 \\
\hline 97 & [60] & $\begin{array}{l}\text { Krishnamurthy P, Ross DD, Nakanishi T, et al. The stem cell marker Bcrp/ABCG2 enhances hypoxic cell survival } \\
\text { through interactions with heme. J Biol Chem. 2004;279(23):24218-24225 }\end{array}$ & 524 \\
\hline 98 & [80] & $\begin{array}{l}\text { Melillo G, Musso T, Sica A, Taylor LS, Cox GW, Varesio L. A hypoxia-responsive element mediates a novel path- } \\
\text { way of activation of the inducible nitric oxide synthase promoter. J Exp Med. 1995;182(6):1683-1693 }\end{array}$ & 518 \\
\hline 99 & [121] & $\begin{array}{l}\text { Shweiki D, Neeman M, Itin A, Keshet E. Induction of vascular endothelial growth factor expression by hypoxia } \\
\text { and by glucose deficiency in multicell spheroids: implications for tumor angiogenesis. Proc Natl Acad Sci U S A. } \\
\text { 1995;92(3):768-772 }\end{array}$ & 516 \\
\hline 100 & [59] & $\begin{array}{l}\text { Koumenis C, Naczki C, Koritzinsky M, et al. Regulation of protein synthesis by hypoxia via activation of the } \\
\text { endoplasmic reticulum kinase PERK and phosphorylation of the translation initiation factor eIF2alpha. Mol Cell } \\
\text { Biol. 2002;22(21):7405-7416 }\end{array}$ & 506 \\
\hline
\end{tabular}

The articles related to "cancer" are not displayed (see Table 2)

*Shows the review articles

these articles by citations. We added to this list the articles related to cancer extracted from Table 1 to create Table 2 with the top-25 articles related to hypoxia and cancer.

A third search was performed only in "sport sciences" journals, with "exercise," "sport," "applied physiology," or "rehabilitation" in the journal title. This search yielded 3113 articles.

\section{Results}

The number of citations of the (bio)medical articles on hypoxia began to increase in the 1960s, while the rise in citations on "hypoxia and cancer" started later, in the end $90 \mathrm{~s}$. The total number of citations is $>68,000$ and $>18,000$ in 2020, respectively (Fig. 1). 
Table 2 Top-25 cited articles on "hypoxia and cancer"

$\begin{array}{lll}\text { Order References } & \text { Citations } \\ \text { number }\end{array}$

number

\begin{tabular}{|c|c|c|c|}
\hline 1 & {$[15]$} & $\begin{array}{l}\text { Carmeliet P, Dor Y, Herbert JM, et al. Role of HIF-1alpha in hypoxia-mediated apoptosis, cell proliferation and } \\
\text { tumour angiogenesis. Nature. 1998;394(6692):485-490 }\end{array}$ & 2045 \\
\hline 2 & [38] & $\begin{array}{l}\text { Graeber TG, Osmanian C, Jacks T, et al. Hypoxia-mediated selection of cells with diminished apoptotic poten- } \\
\text { tial in solid tumours. Nature. 1996;379(6560):88-91 }\end{array}$ & 2032 \\
\hline $3 *$ & [136] & Wilson WR, Hay MP. Targeting hypoxia in cancer therapy. Nature Reviews Cancer. 2011;11(6):393-410 & 1809 \\
\hline $4^{*}$ & [10] & $\begin{array}{l}\text { Brown JM, Wilson WR. Exploiting tumour hypoxia in cancer treatment. Nature reviews Cancer. 2004;4(6):437- } \\
447\end{array}$ & 1745 \\
\hline 5 & [49] & $\begin{array}{l}\text { Hockel M, Schlenger K, Aral B, Mitze M, Schaffer U, Vaupel P. Association between tumor hypoxia and malig- } \\
\text { nant progression in advanced cancer of the uterine cervix. Cancer Res. 1996;56(19):4509-4515 }\end{array}$ & 1508 \\
\hline $6^{*}$ & [128] & $\begin{array}{l}\text { Vaupel P, Mayer A. Hypoxia in cancer: significance and impact on clinical outcome. Cancer Metastasis Rev. } \\
\text { 2007;26(2):225-239 }\end{array}$ & 1460 \\
\hline 7 & [145] & $\begin{array}{l}\text { Zhong H, Chiles K, Feldser D, et al. Modulation of hypoxia-inducible factor 1alpha expression by the epidermal } \\
\text { growth factor/phosphatidylinositol 3-kinase/PTEN/AKT/FRAP pathway in human prostate cancer cells: impli- } \\
\text { cations for tumor angiogenesis and therapeutics. Cancer Res. 2000;60(6):1541-1545 }\end{array}$ & 1280 \\
\hline $8^{*}$ & [92] & $\begin{array}{l}\text { Pouyssegur J, Dayan F, Mazure NM. Hypoxia signalling in cancer and approaches to enforce tumour regression. } \\
\text { Nature. 2006;441(7092):437-443 }\end{array}$ & 1233 \\
\hline $9 *$ & [115] & $\begin{array}{l}\text { Semenza GL. Defining the role of hypoxia-inducible factor } 1 \text { in cancer biology and therapeutics. Oncogene. } \\
\text { 2010;29(5):625-634 }\end{array}$ & 1150 \\
\hline 10 & [91] & $\begin{array}{l}\text { Pennacchietti S, Michieli P, Galluzzo M, Mazzone M, Giordano S, Comoglio PM. Hypoxia promotes invasive } \\
\text { growth by transcriptional activation of the met protooncogene. Cancer Cell. 2003;3(4):347-361 }\end{array}$ & 1008 \\
\hline 11 & [8] & $\begin{array}{l}\text { Brizel DM, Sibley GS, Prosnitz LR, Scher RL, Dewhirst MW. Tumor hypoxia adversely affects the prognosis of } \\
\text { carcinoma of the head and neck. Int J Radiat Oncol Biol Phys. 1997;38(2):285-289 }\end{array}$ & 896 \\
\hline $12^{*}$ & [117] & $\begin{array}{l}\text { Semenza GL. Hypoxia-inducible factors: mediators of cancer progression and targets for cancer therapy. Trends } \\
\text { in Pharmacological Sciences. 2012;33(4):207-214 }\end{array}$ & 894 \\
\hline 13 & [78] & $\begin{array}{l}\text { Maxwell PH, Dachs GU, Gleadle JM, et al. Hypoxia-inducible factor-1 modulates gene expression in solid } \\
\text { tumors and influences both angiogenesis and tumor growth. Proc Natl Acad Sci U S A. 1997;94(15):8104- } \\
8109\end{array}$ & 889 \\
\hline 14 & [70] & $\begin{array}{l}\text { Li Z, Bao S, Wu Q, et al. Hypoxia-inducible factors regulate tumorigenic capacity of glioma stem cells. Cancer } \\
\text { Cell. 2009;15(6):501-513 }\end{array}$ & 847 \\
\hline $15^{*}$ & [7] & $\begin{array}{l}\text { Brezis M, Rosen S. Hypoxia of the renal medulla-its implications for disease. N Engl J Med. 1995;332(10):647- } \\
655\end{array}$ & 842 \\
\hline $16^{*}$ & [57] & Keith B, Simon MC. Hypoxia-inducible factors, stem cells, and cancer. Cell. 2007;129(3):465-472 & 799 \\
\hline 17 & [27] & $\begin{array}{l}\text { Erler JT, Bennewith KL, Cox TR, et al. Hypoxia-induced lysyl oxidase is a critical mediator of bone marrow cell } \\
\text { recruitment to form the premetastatic niche. Cancer Cell. 2009;15(1):35-44 }\end{array}$ & 768 \\
\hline 18 & [96] & $\begin{array}{l}\text { Raval RR, Lau KW, Tran MG, et al. Contrasting properties of hypoxia-inducible factor } 1 \text { (HIF-1) andHIF-2 in } \\
\text { von Hippel-Lindau-associated renal cell carcinoma. Mol Cell Biol. 2005;25(13):5675-5686 }\end{array}$ & 694 \\
\hline 19 & [32] & $\begin{array}{l}\text { Fukuda R, Hirota K, Fan F, Jung YD, Ellis LM, Semenza GL. Insulin-like growth factor } 1 \text { induces hypoxia- } \\
\text { inducible factor 1-mediated vascular endothelial growth factor expression, which is dependent on MAP kinase } \\
\text { and phosphatidylinositol 3-kinase signaling in colon cancer cells. J Biol Chem. 2002;277(41):38205-38211 }\end{array}$ & 672 \\
\hline 20 & [139] & $\begin{array}{l}\text { Xu RH, Pelicano H, Zhou Y, et al. Inhibition of glycolysis in cancer cells: a novel strategy to overcome drug } \\
\text { resistance associated with mitochondrial respiratory defect and hypoxia. Cancer Res. 2005;65(2):613-621 }\end{array}$ & 638 \\
\hline $21^{*}$ & [138] & $\begin{array}{l}\text { Wouters BG, Koritzinsky M. Hypoxia signalling through mTOR and the unfolded protein response in cancer. } \\
\text { Nature Reviews Cancer. 2008;8(11):851-864 }\end{array}$ & 623 \\
\hline 22 & [6] & $\begin{array}{l}\text { Birner P, Schindl M, Obermair A, Plank C, Breitenecker G, Oberhuber G. Overexpression of hypoxia-inducible } \\
\text { factor 1alpha is a marker for an unfavorable prognosis in early-stage invasive cervical cancer. Cancer Res. } \\
\text { 2000;60(17):4693-4696 }\end{array}$ & 611 \\
\hline 23 & [101] & $\begin{array}{l}\text { Sahlgren C, Gustafsson MV, Jin S, Poellinger L, Lendahl U. Notch signaling mediates hypoxia-induced tumor } \\
\text { cell migration and invasion. Proc Natl Acad Sci U S A. 2008;105(17):6392-6397 }\end{array}$ & 588 \\
\hline $24 *$ & [95] & $\begin{array}{l}\text { Rankin EB, Giaccia AJ. The role of hypoxia-inducible factors in tumorigenesis. Cell Death Differ, } 2008 . \\
\text { 15(4):678-85 }\end{array}$ & 586 \\
\hline $25 *$ & [9] & $\begin{array}{l}\text { Brown JM. The hypoxic cell: a target for selective cancer therapy-eighteenth Bruce F. Cain Memorial Award } \\
\text { lecture. Cancer Res. 1999;59(23):5863-5870 }\end{array}$ & 579 \\
\hline
\end{tabular}

\footnotetext{
*Shows the review articles
} 
Fig. 1 A Total citations number per year (1950-2020) of articles on "hypoxia," "hypoxia and cancer," and "hypoxia in sport sciences"; B The respective contribution in the top-100 articles on hypoxia of the molecular, pathophysiology, and physiology approaches is shown. No articles related to clinical or sport (altitude training) applications reached the top-100

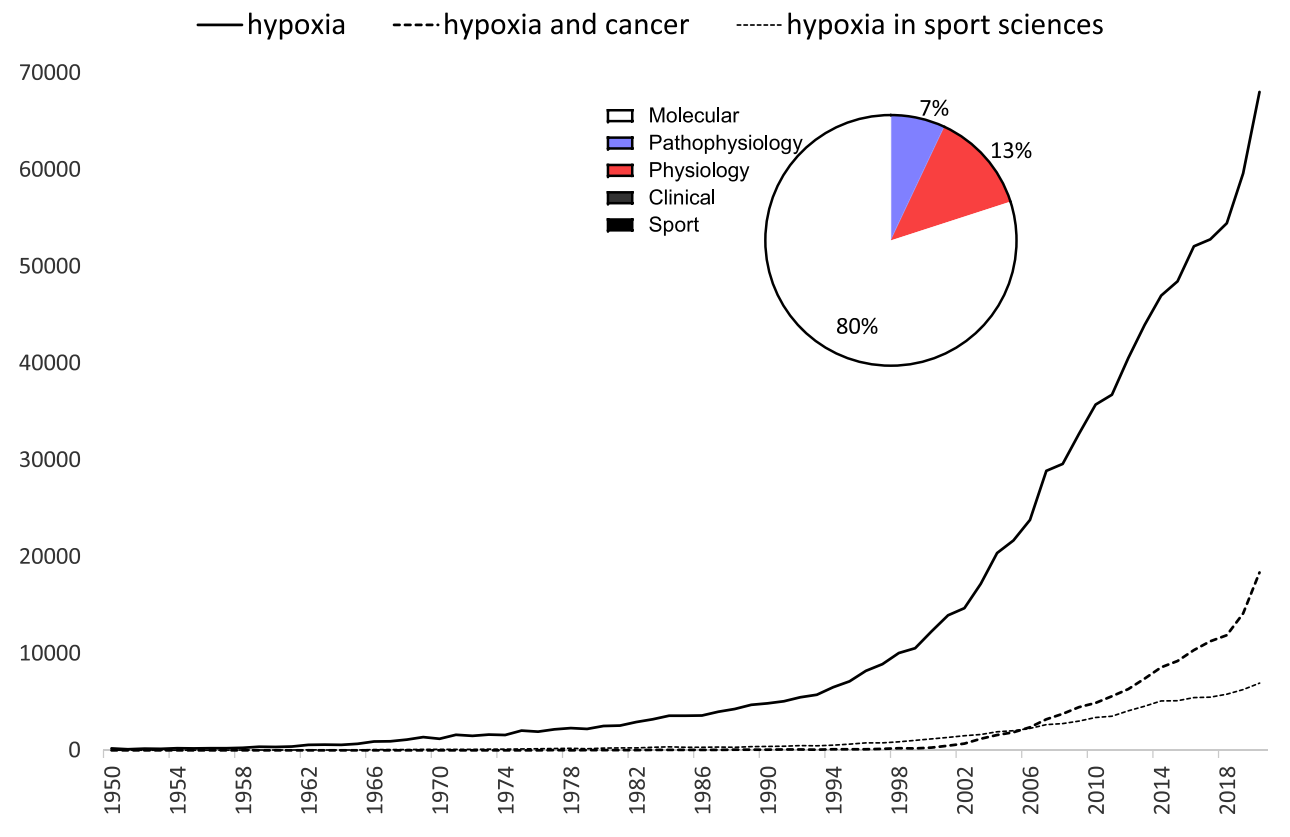

Table 1 displays the top-100 most-cited articles on hypoxia and Table 2 shows the top- 25 articles on hypoxia related to cancer.

The mean number of citations of the top-100 articles on hypoxia (Table 1) is 973 (range: 506-4517) and 28 articles reached $>1000$ citations. The publication years ranged between 1963 and 2014. Of the identified articles, 17 were reviews, of which 7 were (co-)authored by Gregg L. Semenza.

The mean number of citations of the top-100 articles related to cancer is 493 (range 213-2045). Only three articles were published prior 1995 (range: 1978-2018). Ten articles have $>1000$ citations. Overall 31 articles related to cancer (Table 2 displays the top-25, all published since 1995; 11 are review articles) would be in the top-100 articles on hypoxia.

Of the top-100 articles on hypoxia, only 7 were on the pathophysiological responses and risks of hypoxia, 13 on the physiological responses to hypoxia, and most of them (80) on the molecular responses, mainly related to the HIF-1 pathway.

We did not identify any articles on the application of hypoxia either for therapeutic use (i.e., hypoxic conditioning in patients) or for performance enhancement (i.e., altitude training in athletes) in the top 100. However, there is a large increase in the number of citations in the "sport sciences" journals (Fig. 1), starting in the 1960s with an important rise in the last twenty years.

Wang et al. [130] published the most-cited article in 1995. Consequently, to display the impact of the discovery of the HIF pathway on the body of literature related to hypoxia, we arbitrarily chose to analyze two distinct periods (until 1994 vs. since 1995): it is striking that only 12 of the top-100 most-cited articles on hypoxia and only 3 articles of the top-100 articles related to cancer were published prior 1995. Moreover, before 1995, only 5 articles reached 1000 citations. Since 1995, 27 articles reached 1000 citations, most of them on the HIF-1 pathway.

The three journals with the larger number of the top-100 articles published on hypoxia are The Journal of Biological Chemistry (26 articles), PNAS (11), and Molecular and Cellular Biology (8), while the preferred journals for the top-100 articles related to "cancer" were Cancer Research (17), PNAS (7), and British Journal of Cancer (6).

An outstanding point is that the Nobel laureate Gregg Semenza published 27 of these most-cited articles on hypoxia, including 10 with GL Wang as a co-author (including the most cited article in the list).

\section{Discussion}

The presented descriptive overview of the current biomedical literature provides some insights into the evolution of the research related to hypoxia:

1. The mechanistic investigation of how the body adapts to hypoxia is an important topic in biology and medicine since "the responses to oxygen in the cells and organisms is one of the most central physiological adaptation that animals have" (statement of the Nobel assembly).

2. The HIF pathway discovery in the 1990s, which was made possible with the increasing effectiveness of the molecular biology methods, opens the way to many 
medical or pharmacological applications in many diseases, especially cancer. Since the literature on clinical applications of hypoxia is still relatively scarce, harnessing related strategies seems to be still at an early stage and requires future research.

3. Altitude training for sport performance enhancement is an important topic in sport sciences but attracts relatively limited attention compared to the overall hypoxia research field.

There is a long-term interest in medical sciences for hypoxia. This is shown by the increase in the total number of citations starting in the 1960s. Great studies have been published on pathophysiological and systemic physiological responses to acute hypoxia or to adaptations to prolonged exposure. One perfect example is the study by Shweiki et al. [120] on angiogenesis that is the most-cited article (3721 citations) prior 1995.

The scientific importance of the HIF pathway is confirmed by the large majority of publications based on molecular approaches related to HIF. Importantly, 97 of the top-100 articles on hypoxia have been published since 1995 with 27 having $>1000$ citations. Thus, the early 1990s period-characterized by a switch from non-molecular to highly molecular-focused research — could be regarded as the period "when mountains moved." This is further supported indirectly by the recent (end 1990s) increase in citations of the articles on hypoxia and cancer. Unsurprisingly, there is a large number of review articles (i.e., 17 in top100 on "hypoxia"; 11 in the top-25 articles on "hypoxia and cancer") in the most-cited ones. This has to be taken into account since the publication of original data is associated with different citation patterns than the publication of review articles.

Surprisingly, although several molecular articles on cancer suggested clinical potentialities and the fact that the Nobel committee awarded the prize also for the potential clinical applications, to date none of the clinical articles reached the top-100 position yet. While there is an increasing body of literature on the pros and cons of hypoxic conditioning, most of these papers have been published very recently. Similarly, the articles on the application of hypoxia in athletes exhibit a comparable minor impact, although the most-cited article of this field by Levine and Stray-Gundersen [66] reached 493 citations. Of interest is the discrepancy between the continuous increase of citations in "sport sciences" journals (Fig. 1) and the fact that the most-cited articles are almost exclusively in-vitro/in-cellulo molecular studies (Table 1). Our analysis shows that there is no decline in the (applied) physiology studies but the highly cited molecular studies "dilute" their numbers. Similar trends likely occur in many other "biomedical" fields.
One obvious limitation of this type of bibliometric analysis is the relevance of the citations number as metrics for assessing the research impact. Important articles for specific fields (e.g., mainly relevant for clinicians) may be cited more rarely than their (theoretical or practical) impact would suggest.

In conclusion, the discovery of the HIF pathway and of its molecular regulation in the early 1990s has revolutionized the research on hypoxia with the emergence of a considerably growing interest for its link to cancer. However, studies on clinical applications of hypoxia remain of comparatively lower interest yet but are promising.

Funding Open Access funding provided by Université de Lausanne.

Availability of Data and Material Not applicable.

Code Availability Not applicable.

\section{Declarations}

Conflict of interest On behalf of all authors, the corresponding author states that there is no conflict of interest.

Ethical Approval Not applicable.

Open Access This article is licensed under a Creative Commons Attribution 4.0 International License, which permits use, sharing, adaptation, distribution and reproduction in any medium or format, as long as you give appropriate credit to the original author(s) and the source, provide a link to the Creative Commons licence, and indicate if changes were made. The images or other third party material in this article are included in the article's Creative Commons licence, unless indicated otherwise in a credit line to the material. If material is not included in the article's Creative Commons licence and your intended use is not permitted by statutory regulation or exceeds the permitted use, you will need to obtain permission directly from the copyright holder. To view a copy of this licence, visit http://creativecommons.org/licenses/by/4.0/.

\section{References}

1. An WG, Kanekal M, Simon MC, Maltepe E, Blagosklonny MV, Neckers LM. Stabilization of wild-type p53 by hypoxia-inducible factor 1alpha. Nature. 1998;392(6674):405-8.

2. Appelhoff RJ, Tian YM, Raval RR, Turley H, Harris AL, Pugh $\mathrm{CW}$, Ratcliffe PJ, Gleadle JM. Differential function of the prolyl hydroxylases PHD1, PHD2, and PHD3 in the regulation of hypoxia-inducible factor. J Biol Chem. 2004;279(37):38458-65.

3. Arany Z, Huang LE, Eckner R, Bhattacharya S, Jiang C, Goldberg MA, Bunn HF, Livingston DM. An essential role for p300/ CBP in the cellular response to hypoxia. Proc Natl Acad Sci U S A. 1996;93(23):12969-73.

4. Bellot G, Garcia-Medina R, Gounon P, Chiche J, Roux D, Pouysségur J, Mazure NM. Hypoxia-induced autophagy is mediated through hypoxia-inducible factor induction of BNIP3 and BNIP3L via their BH3 domains. Mol Cell Biol. 2009;29(10):2570-81. 
5. Berne RM. Cardiac nucleotides in hypoxia: possible role in regulation of coronary blood flow. Am J Physiol. 1963;204:317-22.

6. Birner P, Schindl M, Obermair A, Plank C, Breitenecker G, Oberhuber G. Overexpression of hypoxia-inducible factor 1 alpha is a marker for an unfavorable prognosis in early-stage invasive cervical cancer. Cancer Res. 2000;60(17):4693-6.

7. Brezis M, Rosen S. Hypoxia of the renal medulla-its implications for disease. N Engl J Med. 1995;332(10):647-55.

8. Brizel DM, Sibley GS, Prosnitz LR, Scher RL, Dewhirst MW. Tumor hypoxia adversely affects the prognosis of carcinoma of the head and neck. Int J Radiat Oncol Biol Phys. 1997;38(2):285-9.

9. Brown JM. The hypoxic cell: a target for selective cancer therapy-eighteenth Bruce F. Cain Memorial Award lecture. Cancer Res. 1999;59(23):5863-70.

10. Brown JM, Wilson WR. Exploiting tumour hypoxia in cancer treatment. Nat Rev Cancer. 2004;4(6):437-47.

11. Bruick RK. Expression of the gene encoding the proapoptotic Nip3 protein is induced by hypoxia. Proc Natl Acad Sci U S A. 2000;97(16):9082-7.

12. Bunn HF, Poyton RO. Oxygen sensing and molecular adaptation to hypoxia. Physiol Rev. 1996;76(3):839-85.

13. Burtscher J, Mallet RT, Burtscher M, Millet GP. Hypoxia and brain aging: neurodegeneration or neuroprotection? Ageing Res Rev. 2021;68:101343.

14. Burtscher J, Millet GP, Burtscher M. Does living at moderate altitudes in Austria affect mortality rates of various causes? An ecological study. BMJ Open. 2021;11(6):e048520.

15. Carmeliet P, Dor Y, Herbert JM, Fukumura D, Brusselmans K, Dewerchin M, Neeman M, Bono F, Abramovitch R, Maxwell P, Koch CJ, Ratcliffe P, Moons L, Jain RK, Collen D, Keshert E. Role of HIF-1alpha in hypoxia-mediated apoptosis, cell proliferation and tumour angiogenesis. Nature. 1998;394(6692):485-90.

16. Carreau A, Hafny-Rahbi BEI, Matejuk A, Grillon C, Kieda C. Why is the partial oxygen pressure of human tissues a crucial parameter? Small molecules and hypoxia. J Cell Mol Med. 2011;15(6):1239-53.

17. Ceradini DJ, Kulkarni AR, Callaghan MJ, Tepper OM, Bastidas N, Kleinman ME, Capla JM, Galiano RD, Levine JP, Gurtner GC. Progenitor cell trafficking is regulated by hypoxic gradients through HIF-1 induction of SDF-1. Nat Med. 2004;10(8):858-64

18. Chandel NS, Maltepe E, Goldwasser E, Mathieu CE, Simon MC, Schumacker PT. Mitochondrial reactive oxygen species trigger hypoxia-induced transcription. Proc Natl Acad Sci U S A. 1998;95(20):11715-20.

19. Chandel NS, McClintock DS, Feliciano CE, Wood TM, Melendez JA, Rodriguez AM, Schumacker PT. Reactive oxygen species generated at mitochondrial complex III stabilize hypoxiainducible factor-1alpha during hypoxia: a mechanism of $\mathrm{O} 2$ sensing. J Biol Chem. 2000;275(33):25130-8.

20. Cockman ME, Masson N, Mole DR, Jaakkola P, Chang GW, Clifford SC, Maher ER, Pugh CW, Ratcliffe PJ, Maxwell PH. Hypoxia inducible factor-alpha binding and ubiquitylation by the von Hippel-Lindau tumor suppressor protein. J Biol Chem. 2000;275(33):25733-41.

21. Dang EV, Barbi J, Yang H-Y, Jinasena D, Yu H, Zheng Y, Bordman Z, Fu J, Kim Y, Yen H-R, Luo W, Zeller K, Shimoda L, Topalian SL, Semenza GL, Dang CV, Pardoll DM, Pan F. Control of T(H)17/T(reg) balance by hypoxia-inducible factor 1. Cell. 2011;146(5):772-84

22. Daut J, Maier-Rudolph W, von Beckerath N, Mehrke G, Günther K, Goedel-Meinen L. Hypoxic dilation of coronary arteries is mediated by ATP-sensitive potassium channels. Science. 1990;247(4948):1341-4.
23. Dill DB, Adams WC. Maximal oxygen uptake at sea level and at 3,090-m altitude in high school champion runners. J Appl Physiol. 1971;30(6):854-9.

24. Duranteau J, Chandel NS, Kulisz A, Shao Z, Schumacker PT. Intracellular signaling by reactive oxygen species during hypoxia in cardiomyocytes. J Biol Chem. 1998;273(19):11619-24.

25. Eltzschig HK, Carmeliet P. Hypoxia and inflammation. N Engl J Med. 2011;364(7):656-65.

26. Ema M, Taya S, Yokotani N, Sogawa K, Matsuda Y, Fujii-Kuriyama Y. A novel bHLH-PAS factor with close sequence similarity to hypoxia-inducible factor 1 alpha regulates the VEGF expression and is potentially involved in lung and vascular development. Proc Natl Acad Sci U S A. 1997;94(9):4273-8.

27. Erler JT, Bennewith KL, Cox TR, Lang G, Bird D, Koong A, Le Q-T, Giaccia AJ. Hypoxia-induced lysyl oxidase is a critical mediator of bone marrow cell recruitment to form the premetastatic niche. Cancer Cell. 2009;15(1):35-44.

28. Faeh D, Gutzwiller F, Bopp M, Swiss National Cohort Study Group. Lower mortality from coronary heart disease and stroke at higher altitudes in Switzerland. Circulation. 2009;120(6):495.

29. Faeh D, Moser A, Panczak R, Bopp M, Röösli M, Spoerri A, Swiss National Cohort Study Group. Independent at heart: persistent association of altitude with ischaemic heart disease mortality after consideration of climate, topography and built environment. J Epidemiol Community Health. 2016;70(8):798-806.

30. Fasanaro P, D'Alessandra Y, Stefano VD, Melchionna R, Romani S, Pompilio G, Capogrossi MC, Martelli F. MicroRNA-210 modulates endothelial cell response to hypoxia and inhibits the receptor tyrosine kinase ligand Ephrin-A3. J Biol Chem. 2008;283(23):15878-83.

31. Forsythe JA, Jiang BH, Iyer NV, Agani F, Leung SW, Koos RD, Semenza GL. Activation of vascular endothelial growth factor gene transcription by hypoxia-inducible factor 1 . Mol Cell Biol. 1996;16(9):4604-13.

32. Fukuda R, Hirota K, Fan F, Jung YD, Ellis LM, Semenza GL. Insulin-like growth factor 1 induces hypoxia-inducible factor 1-mediated vascular endothelial growth factor expression, which is dependent on MAP kinase and phosphatidylinositol 3-kinase signaling in colon cancer cells. J Biol Chem. 2002;277(41):38205-11.

33. Fukuda R, Zhang H, Kim J, Shimoda L, Dang CV, Semenza GL. HIF-1 regulates cytochrome oxidase subunits to optimize efficiency of respiration in hypoxic cells. Cell. 2007;129(1):111-22.

34. Gemmill CL. Aviation physiology. Annu Rev Physiol. 1946;8:499-514.

35. Gerber HP, Condorelli F, Park J, Ferrara N. Differential transcriptional regulation of the two vascular endothelial growth factor receptor genes. Flt-1, but not Flk-1/KDR, is up-regulated by hypoxia. J Biol Chem. 1997;272(38):23659-67.

36. Girard O, Brocherie F, Millet GP. Effects of altitude/hypoxia on single- and multiple-sprint performance: a comprehensive review. Sports Med. 2017;47(10):1931-49.

37. Graeber TG, Peterson JF, Tsai M, Monica K, Fornace AJ, Giaccia AJ. Hypoxia induces accumulation of p53 protein, but activation of a G1-phase checkpoint by low-oxygen conditions is independent of p53 status. Mol Cell Biol. 1994;14(9):6264-77.

38. Graeber TG, Osmanian C, Jacks T, Housman DE, Koch CJ, Lowe S, Giaccia AJ. Hypoxia-mediated selection of cells with diminished apoptotic potential in solid tumours. Nature. 1996;379(6560):88-91.

39. Gustafsson MV, Zheng X, Pereira T, Gradin K, Jin S, Lundkvist J, Ruas JL, Poellinger L, Lendahl U, Bondesson M. 
Hypoxia requires notch signaling to maintain the undifferentiated cell state. Dev Cell. 2005;9(5):617-28.

40. Guzy RD, Hoyos B, Robin E, Chen H, Liu L, Mansfield KD, Simon MC, Hammerling U, Schumacker PT. Mitochondrial complex III is required for hypoxia-induced ROS production and cellular oxygen sensing. Cell Metab. 2005;1(6):401-8.

41. Guzy RD, Schumacker PT. Oxygen sensing by mitochondria at complex III: the paradox of increased reactive oxygen species during hypoxia. Exp Physiol. 2006;91(5):807-19.

42. Hackett PH, Rennie D, Levine HD. The incidence, importance, and prophylaxis of acute mountain sickness. Lancet. 1976;2(7996):1149-55.

43. Hackett PH, Roach RC. High-altitude illness. N Engl J Med. 2001;345(2):107-14.

44. Hagen T, Taylor CT, Lam F, Moncada S. Redistribution of intracellular oxygen in hypoxia by nitric oxide: effect on HIF1alpha. Science. 2003;302(5652):1975-8.

45. Hewitson KS, McNeill LA, Riordan MV, Tian YM, Bullock AN, Welford RW, Elkins JM, Oldham NJ, Bhattacharya S, Gleadle JM. Hypoxia-inducible factor (HIF) asparagine hydroxylase is identical to factor inhibiting HIF (FIH) and is related to the cupin structural family. J Biol Chem. 2002;277(29):26351-5.

46. Hirsila M, Koivunen P, Günzler V, Kivirikko KI, Myllyharju J. Characterization of the human prolyl 4-hydroxylases that modify the hypoxia-inducible factor. J Biol Chem. 2003;278(33):30772-80.

47. Hochachka PW. Defense strategies against hypoxia and hypothermia. Science. 1986;231(4735):234-41.

48. Hochachka PW, Buck LT, Doll CJ, Land SC. Unifying theory of hypoxia tolerance: molecular/metabolic defense and rescue mechanisms for surviving oxygen lack. Proc Natl Acad Sci U S A. 1996;93(18):9493-8.

49. Hockel M, Schlenger K, Aral B, Mitze M, Schaffer U, Vaupel P. Association between tumor hypoxia and malignant progression in advanced cancer of the uterine cervix. Cancer Res. 1996;56(19):4509-15.

50. Hu CJ, Wang LY, Chodosh LA, Keith B, Simon MC. Differential roles of hypoxia-inducible factor 1alpha (HIF-1alpha) and HIF-2alpha in hypoxic gene regulation. Mol Cell Biol. 2003;23(24):9361-74.

51. Huang LE, Arany Z, Livingston DM, Bunn HF. Activation of hypoxia-inducible transcription factor depends primarily upon redox-sensitive stabilization of its alpha subunit. J Biol Chem. 1996;271(50):32253-9.

52. Hudson CC, Liu M, Chiang GG, Otterness DM, Abraham RT. Regulation of hypoxia-inducible factor 1alpha expression and function by the mammalian target of rapamycin. Mol Cell Biol. 2002;22(20):7004-14.

53. Iliopoulos O, Levy AP, Jiang C, Kaelin WG, Goldberg MA. Negative regulation of hypoxia-inducible genes by the von HippelLindau protein. Proc Natl Acad Sci U S A. 1996;93(20):10595-9.

54. Isaacs JS, Jung YJ, Mimnaugh EG, Martinez A, Cuttitta F, Neckers LM. Hsp90 regulates a von Hippel-Lindau-independent hypoxia-inducible factor-1 alpha-degradative pathway. J Biol Chem. 2002;277(33):29936-44.

55. Jiang BH, Rue E, Wang GL, Roe R, Semenza GL. Dimerization, DNA binding, and transactivation properties of hypoxiainducible factor 1. J Biol Chem. 1996;271(30):17771-8.

56. Kallio PJ, Wilson WJ, O'Brien S, Makino Y, Poellinger L. Regulation of the hypoxia-inducible transcription factor 1alpha by the ubiquitin-proteasome pathway. J Biol Chem. 1999;274(10):6519-25.

57. Keith B, Simon MC. Hypoxia-inducible factors, stem cells, and cancer. Cell. 2007;129(3):465-72.

58. Kim JW, Tchernyshyov I, Semenza GL, Dang CV. HIF-1-mediated expression of pyruvate dehydrogenase kinase: a metabolic switch required for cellular adaptation to hypoxia. Cell Metab. 2006;3(3):177-85

59. Koumenis C, Naczki C, Koritzinsky M, Rastani S, Diehl A, Sonenberg N, Koromilas A, Wouters BG. Regulation of protein synthesis by hypoxia via activation of the endoplasmic reticulum kinase PERK and phosphorylation of the translation initiation factor eIF2alpha. Mol Cell Biol. 2002;22(21):7405-16.

60. Krishnamurthy P, Ross DD, Nakanishi T, Bailey-Dell K, Zhou S, Mercer KE, Sarkadi B, Sorrentino BP, Schuetz JD. The stem cell marker Bcrp/ABCG2 enhances hypoxic cell survival through interactions with heme. J Biol Chem. 2004;279(23):24218-25.

61. Kulshreshtha R, Ferracin M, Wojcik SE, Garzon R, Alder H, Agosto-Perez FJ, Davuluri R, Liu CG, Croce CM, Negrini M, Calin GA, Ivan M. A microRNA signature of hypoxia. Mol Cell Biol. 2007;27(5):1859-67.

62. Lando D, Peet DJ, Whelan DA, Gorman JJ, Whitelaw ML. Asparagine hydroxylation of the HIF transactivation domain a hypoxic switch. Science. 2002;295(5556):858-61.

63. Laughner E, Taghavi P, Chiles K, Mahon PC, Semenza GL. HER2 (neu) signaling increases the rate of hypoxia-inducible factor 1alpha (HIF-1alpha) synthesis: novel mechanism for HIF1-mediated vascular endothelial growth factor expression. Mol Cell Biol. 2001;21(12):3995-4004.

64. Lavoisier A. Mémoire sur la combustion en général. Mémoires de l'Académie des sciences. 1777;592.

65. Lee PJ, Jiang BH, Chin BY, Iyer NV, Alam J, Semenza GL, Choi AMK. Hypoxia-inducible factor-1 mediates transcriptional activation of the heme oxygenase- 1 gene in response to hypoxia. J Biol Chem. 1997;272(9):5375-81.

66. Levine BD, Stray-Gundersen J. "Living high-training low": effect of moderate-altitude acclimatization with low-altitude training on performance. J Appl Physiol. 1997;83(1):102-12.

67. Levy AP, Levy NS, Wegner S, Goldberg MA. Transcriptional regulation of the rat vascular endothelial growth factor gene by hypoxia. J Biol Chem. 1995;270(22):13333-40.

68. Levy NS, Chung S, Furneaux H, Levy AP. Hypoxic stabilization of vascular endothelial growth factor mRNA by the RNA-binding protein HuR. J Biol Chem. 1998;273(11):6417-23.

69. Levy AP, Levy NS, Goldberg MA. Post-transcriptional regulation of vascular endothelial growth factor by hypoxia. J Biol Chem. 1996;271(5):2746-53.

70. Li Z, Bao S, Wu Q, Wang H, Eyler C, Sathornsumetee S, Shi Q, Cao Y, Lathia J, McLendon RE, Hjelmeland AB, Rich JN. Hypoxia-inducible factors regulate tumorigenic capacity of glioma stem cells. Cancer Cell. 2009;15(6):501-13.

71. Li C, Jackson RM. Reactive species mechanisms of cellular hypoxia-reoxygenation injury. Am J Physiol Cell Physiol. 2002;282(2):C227-41.

72. Liu L, Feng D, Chen G, Chen M, Zheng Q, Song P, Ma Q, Zhu C, Wang R, Qi W, Huang L, Xue P, Li B, Wang X, Jin H, Wang J, Yang F, Liu P, Zhu Y, Sui S, Chen Q. Mitochondrial outer-membrane protein FUNDC1 mediates hypoxia-induced mitophagy in mammalian cells. Nat Cell Biol. 2012;14(2):177-85.

73. Long term domiciliary oxygen therapy in chronic hypoxic cor pulmonale complicating chronic bronchitis and emphysema. Report of the Medical Research Council Working Party. Lancet. 1981;1(8222):681-6.

74. Lundby C, Millet GP, Calbet JA, Bärtsch P, Subudhi AW. Does "altitude training" increase exercise performance in elite athletes? Br J Sports Med. 2012;46(11):792-5.

75. Luo W, Hu H, Chang R, Zhong J, Knabel M, O'Meally R, Cole RN, Pandey A, Semenza GL. Pyruvate kinase M2 is a PHD3stimulated coactivator for hypoxia-inducible factor 1 . Cell. 2011;145(5):732-44. 
76. Majmundar AJ, Wong WJ, Simon MC. Hypoxia-inducible factors and the response to hypoxic stress. Mol Cell. 2010;40(2):294-309.

77. Mallet RT, Manukhina EB, Ruelas SS, Caffrey JL, Fred DH. Cardioprotection by intermittent hypoxia conditioning: evidence, mechanisms and therapeutic potential. Am J Physiol Heart Circ Physiol. 2018;315(2):H216-32.

78. Maxwell PH, Dachs GU, Gleadle JM, Nicholls LG, Harris AL, Stratford IJ, Hankinson O, Pugh CW, Ratcliffe PJ. Hypoxiainducible factor-1 modulates gene expression in solid tumors and influences both angiogenesis and tumor growth. Proc Natl Acad Sci U S A. 1997;94(15):8104-9.

79. Maxwell PH, Wiesener MS, Chang GW, Clifford SC, Vaux EC, Cockman ME, Wykoff CC, Pugh CW, Maher ER, Ratcliffe PJ. The tumour suppressor protein VHL targets hypoxiainducible factors for oxygen-dependent proteolysis. Nature. 1999;399(6733):271-5.

80. Melillo G, Musso T, Sica A, Taylor LS, Cox GW, Varesio L. A hypoxia-responsive element mediates a novel pathway of activation of the inducible nitric oxide synthase promoter. J Exp Med. 1995;182(6):1683-93.

81. Metallo CM, Gameiro PA, Bell EL, Mattaini KR, Yang J, Hiller K, Jewell CM, Johnson ZR, Irvine DJ, Guarente L, Kelleher JK, Vander Heiden MG, Iliopoulos O, Stephanopoulos G. Reductive glutamine metabolism by IDH1 mediates lipogenesis under hypoxia. Nature. 2011;481(7381):380-4.

82. Millet GP, Girard O, Beard A, Brocherie F. Repeated sprint training in hypoxia-an innovative method. Deutsche Zeitschrift für Sportmedizin. 2019;70:115-22.

83. Moslehi J, Rathmell WK. The 2019 Nobel Prize honors fundamental discoveries in hypoxia response. J Clin Invest. 2020;130(1):4-6.

84. Mu J, Brozinick JT, Valladares O, Bucan M, Birnbaum MJ. A role for AMP-activated protein kinase in contraction- and hypoxia-regulated glucose transport in skeletal muscle. Mol Cell. 2001;7(5):1085-94.

85. Mukhopadhyay D, Tsiokas L, Zhou XM, Foster D, Brugge JS, Sukhatme VP. Hypoxic induction of human vascular endothelial growth factor expression through c-Src activation. Nature. 1995;375(6532):577-81.

86. Neonatal Inhaled Nitric Oxide Study G. Inhaled nitric oxide in full-term and nearly full-term infants with hypoxic respiratory failure. N Engl J Med. 1997;336(9):597-604.

87. Noman MZ, Saoussen K, Giacomo D, Philippe D. PD-L1 is a novel direct target of HIF-1alpha, and its blockade under hypoxia enhanced MDSC-mediated T cell activation. J Exp Med. 2014;211(5):781-90.

88. Ohh M, Park CW, Ivan M, Hoffman MA, Kaelin WG. Ubiquitination of hypoxia-inducible factor requires direct binding to the beta-domain of the von Hippel-Lindau protein. Nat Cell Biol. 2000;2(7):423-7.

89. Papandreou I, Cairns RA, Fontana L, Lim AL, Denko NC. HIF-1 mediates adaptation to hypoxia by actively downregulating mitochondrial oxygen consumption. Cell Metab. 2006;3(3):187-97.

90. Parmar K, Mauch P, Vergilio JA, Sackstein R, Down JD. Distribution of hematopoietic stem cells in the bone marrow according to regional hypoxia. Proc Natl Acad Sci U S A. 2007;104(13):5431-6.

91. Pennacchietti S, Michieli P, Galluzzo M, Mazzone M, Giordano $\mathrm{S}$, Comoglio PM. Hypoxia promotes invasive growth by transcriptional activation of the met protooncogene. Cancer Cell. 2003;3(4):347-61.

92. Pouyssegur J, Dayan F, Mazure NM. Hypoxia signalling in cancer and approaches to enforce tumour regression. Nature. 2006;441(7092):437-43.
93. Priestley J. Experiments and observations on different kinds of air. Printed for J. Johnson. 1775;72.

94. Pugh CW, Ratcliffe PJ. Regulation of angiogenesis by hypoxia: role of the HIF system. Nat Med. 2003;9(6):677-84.

95. Rankin EB, Giaccia AJ. The role of hypoxia-inducible factors in tumorigenesis. Cell Death Differ. 2008;15(4):678-85.

96. Raval RR, Lau KW, Tran MGB, Sowter HM, Mandriota SJ, Li JL, Pugh CW, Maxwell PH, Harris AL, Ratcliffe PJ. Contrasting properties of hypoxia-inducible factor 1 (HIF-1) and HIF-2 in von Hippel-Lindau-associated renal cell carcinoma. Mol Cell Biol. 2005;25(13):5675-86.

97. Richalet JP. The scientific observatories on Mont Blanc. High Alt Med Biol. 2001;2(1):57-68.

98. Richalet JP. The invention of hypoxia. J Appl Physiol. 2021;130(5):1573-82.

99. Rius J, Guma M, Schachtrup C, Akassoglou K, Zinkernagel AS, Nizet V, Johnson RS, Haddad GG, Karin M. NF-kappaB links innate immunity to the hypoxic response through transcriptional regulation of HIF-1alpha. Nature. 2008;453(7196):807-11.

100. Rubanyi GM, Vanhoutte PM. Hypoxia releases a vasoconstrictor substance from the canine vascular endothelium. J Physiol. 1985;364:45-56.

101. Sahlgren C, Gustafsson MV, Jin S, Poellinger L, Lendahl U. Notch signaling mediates hypoxia-induced tumor cell migration and invasion. Proc Natl Acad Sci U S A. 2008;105(17):6392-7.

102. Salceda S, Caro J. Hypoxia-inducible factor 1alpha (HIF1alpha) protein is rapidly degraded by the ubiquitin-proteasome system under normoxic conditions. Its stabilization by hypoxia depends on redox-induced changes. J Biol Chem. 1997;272(36):22642-7.

103. Scheele C. d. Königl. Schwed. Acad. d. Wissenschaft. Mitgliedes, Chemische Abhandlung von der Luft und dem Feuer. Uppsala and Liepzig: Magnus Swederus; 1777.

104. Schioppa T, Uranchimeg B, Saccani A, Biswas SK, Doni A, Rapisarda A, Bernasconi S, Saccani S, Nebuloni M, Vago L. Regulation of the chemokine receptor CXCR4 by hypoxia. J Exp Med. 2003;198(9):1391-402.

105. Schmedtje JF Jr, YS Ji, Liu WL, DuBois RN, Runge MS. Hypoxia induces cyclooxygenase-2 via the NF-kappaB p65 transcription factor in human vascular endothelial cells. J Biol Chem. 1997;272(1):601-8.

106. Semenza GL, Nejfelt MK, Chi SM, Antonarakis SE. Hypoxiainducible nuclear factors bind to an enhancer element located 3 ' to the human erythropoietin gene. Proc Natl Acad Sci U S A. 1991;88(13):5680-4.

107. Semenza GL, Roth PH, Fang HM, Wang GL. Transcriptional regulation of genes encoding glycolytic enzymes by hypoxiainducible factor 1. J Biol Chem. 1994;269(38):23757-63.

108. Semenza GL, Jiang BH, Leung SW, Passantino R, Concordet JP, Maire P, Giallongo A. Hypoxia response elements in the aldolase A, enolase 1, and lactate dehydrogenase A gene promoters contain essential binding sites for hypoxia-inducible factor 1 . J Biol Chem. 1996;271(51):32529-37.

109. Semenza GL. Regulation of mammalian O2 homeostasis by hypoxia-inducible factor 1. Annu Rev Cell Dev Biol. 1999;15:551-78.

110. Semenza GL. HIF-1: mediator of physiological and pathophysiological responses to hypoxia. J Appl Physiol. 2000;88(4):1474-80.

111. Semenza GL. HIF-1, O(2), and the 3 PHDs: how animal cells signal hypoxia to the nucleus. Cell. 2001;107(1):1-3.

112. Semenza GL. HIF-1 and mechanisms of hypoxia sensing. Curr Opin Cell Biol. 2001;13(2):167-71. 
113. Semenza GL. Hypoxia-inducible factor 1: oxygen homeostasis and disease pathophysiology. Trends Mol Med. 2001;7(8):345-50.

114. Semenza GL. Regulation of oxygen homeostasis by hypoxiainducible factor 1. Physiology (Bethesda). 2009;24:97-106.

115. Semenza GL. Defining the role of hypoxia-inducible factor 1 in cancer biology and therapeutics. Oncogene. 2010;29(5):625-34.

116. Semenza GL. Hypoxia-inducible factors in physiology and medicine. Cell. 2012;148(3):399-408.

117. Semenza GL. Hypoxia-inducible factors: mediators of cancer progression and targets for cancer therapy. Trends Pharmacol Sci. 2012;33(4):207-14.

118. Shankaran S. Whole-body hypothermia for neonates with hypoxic-ischemic encephalopathy. $\mathrm{N}$ Engl J Med. 2005;353(15):1574-84.

119. Shimizu S, Eguchi Y, Kosaka H, Kamiike W, Matsuda H, Tsujimoto Y. Prevention of hypoxia-induced cell death by Bcl-2 and Bcl-xL. Nature. 1995;374(6525):811-3.

120. Shweiki D, Itin A, Soffer D, Keshet E. Vascular endothelial growth factor induced by hypoxia may mediate hypoxia-initiated angiogenesis. Nature. 1992;359(6398):843-5.

121. Shweiki D, Neeman M, Itin A, Keshet E. Induction of vascular endothelial growth factor expression by hypoxia and by glucose deficiency in multicell spheroids: implications for tumor angiogenesis. Proc Natl Acad Sci U S A. 1995;92(3):768-72.

122. Simonson TS, Yang Y, Huff CD, Yun H, Qin G, Witherspoon DJ, Bai Z, Lorenzo FR, Xing J, Jorde LB, Prchal JT, Ge R. Genetic evidence for high-altitude adaptation in Tibet. Science. 2010;329(5987):72-5.

123. Simsek T, Kocabas F, Zheng J, Deberardinis RJ, Mahmoud AI, Olson EN, Schneider JW, Zhang CC, Sadek HA. The distinct metabolic profile of hematopoietic stem cells reflects their location in a hypoxic niche. Cell Stem Cell. 2010;7(3):380-90.

124. Somjen GG. Mechanisms of spreading depression and hypoxic spreading depression-like depolarization. Physiol Rev. 2001;81(3):1065-96.

125. Trio Wins Nobel for Hypoxia Discoveries. Cancer Discov. 2019;9(12):1636-7.

126. Ullah MS, Davies AJ, Halestrap AP. The plasma membrane lactate transporter MCT4, but not MCT1, is up-regulated by hypoxia through a HIF-1alpha-dependent mechanism. J Biol Chem. 2006;281(14):9030-7.

127. Vanden Hoek TL, Becker LB, Shao Z, Li C, Schumacker PT. Reactive oxygen species released from mitochondria during brief hypoxia induce preconditioning in cardiomyocytes. J Biol Chem. 1998;273(29):18092-8.

128. Vaupel P, Mayer A. Hypoxia in cancer: significance and impact on clinical outcome. Cancer Metastasis Rev. 2007;26(2):225-39.

129. Walmsley SR, Print C, Farahi N, Peyssonnaux C, Johnson RS, Cramer T, Sobolewski A, Condliffe AM, Cowburn AS, Johnson $\mathrm{N}$, Chilvers ER. Hypoxia-induced neutrophil survival is mediated by HIF-1alpha-dependent NF-kappaB activity. J Exp Med. 2005;201(1):105-15.

130. Wang GL, Jiang BH, Rue EA, Semenza GL. Hypoxia-inducible factor 1 is a basic-helix-loop-helix-PAS heterodimer regulated by cellular O2 tension. Proc Natl Acad Sci U S A. 1995;92(12):5510-4.

131. Wang GL, Semenza GL. General involvement of hypoxia-inducible factor 1 in transcriptional response to hypoxia. Proc Natl Acad Sci U S A. 1993;90(9):4304-8.

132. Wang GL, Semenza GL. Characterization of hypoxia-inducible factor 1 and regulation of DNA binding activity by hypoxia. J Biol Chem. 1993;268(29):21513-8.
133. Wang GL, Semenza GL. Purification and characterization of hypoxia-inducible factor 1. J Biol Chem. 1995;270(3):1230-7.

134. West JB. 100th anniversary of the Anglo-American Pikes Peak expedition. High Alt Med Biol. 2011;12(3):189-90.

135. Wiesner S, Haufe S, Engeli S, Mutschler H, Haas U, Luft FC, Jordan J. Influences of normobaric hypoxia training on physical fitness and metabolic risk markers in overweight to obese subjects. Obesity (Silver Spring). 2010;18(1):116-20.

136. Wilson WR, Hay MP. Targeting hypoxia in cancer therapy. Nat Rev Cancer. 2011;11(6):393-410.

137. Wise DR, Ward PS, Shay JES, Cross JR, Gruber JJ, Sachdeva UM, Platt JM, DeMatteo RG, Simon MC, Thompson CB. Hypoxia promotes isocitrate dehydrogenase-dependent carboxylation of alpha-ketoglutarate to citrate to support cell growth and viability. Proc Natl Acad Sci U S A. 2011;108(49):19611-6.

138. Wouters BG, Koritzinsky M. Hypoxia signalling through mTOR and the unfolded protein response in cancer. Nat Rev Cancer. 2008;8(11):851-64.

139. Xu RH, Pelicano H, Zhou Y, Carew JS, Feng L, Bhalla KN, Keating MJ, Huang P. Inhibition of glycolysis in cancer cells: a novel strategy to overcome drug resistance associated with mitochondrial respiratory defect and hypoxia. Cancer Res. 2005;65(2):613-21.

140. Yaffe K, Laffan AM, Harrison SL, Redline S, Spira AP, Ensrud KE, Ancoli-Israel S, Stone KL. Sleep-disordered breathing, hypoxia, and risk of mild cognitive impairment and dementia in older women. JAMA. 2011;306(6):613-9.

141. Ye J, Gao Z, Yin J, He Q. Hypoxia is a potential risk factor for chronic inflammation and adiponectin reduction in adipose tissue of ob/ob and dietary obese mice. Am J Physiol Endocrinol Metab. 2007;293(4):E1118-28.

142. Yi X, Liang Y, Huerta-Sanchez E, Jin X, Cuo ZX, Pool JE, Xu X, Jiang H, Vinckenbosch N, Korneliussen TS, Zheng H, Liu T, He W, Li K, Luo R, Nie X, Wu H, Zhao M, Cao H, Zou J, Shan Y, Li S, Yang Q, Asan, Ni P, Tian G, Xu J, Liu X, Jiang T, Wu R, Zhou G, Tang M, Qin J, Wang T, Feng S, Li G, Huasang, Luosang J, Wang W, Chen F, Wang Y, Zheng X, Li Z, Bianba Z, Yang G, Wang X, Tang S, Gao G, Chen Y, Luo Z, Gusang L, Cao Z, Zhang Q, Ouyang W, Ren X, Liang H, Zheng H, Huang Y, Li J, Bolund L, Kristiansen K, Li Y, Zhang Y, Zhang X, Li R, Li S, Yang H, Nielsen R, Wang J, Wang J. Sequencing of 50 human exomes reveals adaptation to high altitude. Science. 2010;329(5987):75-8.

143. Yoshida Y, Takahashi K, Okita K, Ichisaka T, Yamanaka S. Hypoxia enhances the generation of induced pluripotent stem cells. Cell Stem Cell. 2009;5(3):237-41.

144. Zhang H, Bosch-Marce M, Shimoda LA, Tan YS, Baek JH, Wesley JB, Gonzalez FJ, Semenza GL. Mitochondrial autophagy is an HIF-1-dependent adaptive metabolic response to hypoxia. J Biol Chem. 2008;283(16):10892-903.

145. Zhong $\mathrm{H}$. Modulation of hypoxia-inducible factor 1alpha expression by the epidermal growth factor/phosphatidylinositol 3-kinase/PTEN/AKT/FRAP pathway in human prostate cancer cells: implications for tumor angiogenesis and therapeutics. Cancer Res. 2000;60(6):1541-5. 